\title{
Remediation of Dicofol Type Ddts-Contaminated Sediments by Ferrous Activated Sodium Persulfate Oxidation
}

\author{
Chun-You Zhu ${ }^{1}$, Peng Bao ${ }^{2}$, Yu-Xin $\mathrm{Ba}^{1}$, Jing Hua ${ }^{1}$, Xiao-Ning Liu ${ }^{1}$, Guo-Hua Hou ${ }^{2}$, Chun-Zao $\mathrm{Liu}^{2} \&$ \\ Zheng-Yi Hu${ }^{1}$ \\ ${ }^{1}$ College of Resources and Environment, University of Chinese Academy of Sciences, Beijing, P. R. China \\ ${ }^{2}$ State Key Lab of Urban and Regional Ecology, Research Center for Eco-Environmental Sciences, Chinese \\ Academy of Sciences, Beijing, P. R. China \\ Correspondence: Zheng-Yi Hu, College of Resources and Environment, University of Chinese Academy of \\ Sciences, 19A, Yuquan Road, Beijing 100049, China. Tel: 86-10-8825-6542. E-mail: zhyhu@ucas.ac.cn
}

Received: March 15, 2013 Accepted: April 22, 2013 Online Published: May 27, 2013

doi:10.5539/ep.v2n3p30 URL: http://dx.doi.org/10.5539/ep.v2n3p30

\begin{abstract}
In recent years, contamination by dicofol-type DDTs has attracted immense concern as a new source of DDT pollution. In this study, sediment samples from a dicofol manufacturing factory in Tianjing, China exhibited serious DDT contamination [ $p, p^{\prime}$-DDE $\left(115.27 \mathrm{mg} \mathrm{kg}^{-1}\right)$ and $p, p^{\prime}$-DDT $\left.\left(11.84 \mathrm{mg} \mathrm{kg}^{-1}\right)\right]$. Results of the batch experiments showed that total DDT degradation rates increase as $\mathrm{S}_{2} \mathrm{O}_{8}{ }^{2-} / \mathrm{Fe}^{2+}$ molar ratios increase. The $\mathrm{S}_{2} \mathrm{O}_{8}{ }^{2-} / \mathrm{Fe}^{2+}$ molar ratios used in this study were as follows: $60 / 10<10 / 30<20 / 30<60 / 50<60 / 20<40 / 30<$ $60 / 40<60 / 30<80 / 30$. Their corresponding degradation rates were $31,43,52,69,70,71,72,89$, and $91 \mu \mathrm{g} \mathrm{g}^{-1}$, respectively. The optimal $\mathrm{S}_{2} \mathrm{O}_{8}{ }^{2-} / \mathrm{Fe}^{2+}$ molar ratio was $60 / 30$, which resulted in $64 \%$ and $96 \%$ degradation of $p, p^{\prime}$-DDE and $p, p^{\prime}$-DDT, respectively. However, when an excessive amount of ferrous ion was used $\left(<\mathrm{S}_{2} \mathrm{O}_{8}{ }^{2-} / \mathrm{Fe}^{2+}\right.$ molar ratio of $\left.60 / 30\right)$, then competition for $\mathrm{SO}_{4}{ }^{-}$between ferrous ion and DDTs resulted in decreased DDT degradation efficiency and increased persulfate decomposition (represented by the generated amount of sulfate). Our results implied that a slow and steady production of sulfate free radicals is favorable for DDT degradation, and that $\mathrm{Fe}^{2+}$ availability plays an important role in controlling persulfate reactions activated by ferrous ion. $\mathrm{Fe}^{2+}$-activated persulfate oxidation may be significant in developing environment friendly and fast-remediation options for DDT-contaminated sediments and soil. Therefore, this study contributes to current knowledge on remediating DDT contamination.
\end{abstract}

Keywords: sediments, dicofol-type DDT contamination, persulfate, ferrous ion, oxidative degradation

\section{Introduction}

DDT [1,1,1-trichoro-2,2-bis( $p$-chlorophenyl)-ethane] is one of the persistent organic pollutants (POPs) identified by the Stockholm Convention on POPs which has been extensively used for controlling agricultural pests and disease-carrying insects such as malaria vectors (Zitko, 2003; Kamanavalli \& Ninnekar, 2004). DDT is more stable than other organochlorine pollutants because of its chlorinated aliphatic and aromatic structures. Exposure to DDTs (DDT and its homologues) may damage the human nervous and reproductive systems (Guo et al., 2009). Although the manufacture and application of DDTs have been restricted since the 1970s because of their negative effects, traces of DDTs can still be detected in air, water, soil, sediments, and organisms (Bettinetti et al., 2008; Yao et al., 2006). Moreover, the 2001 Stockholm Convention on POPs still allows the use of DDTs in several countries, such as South Africa, to control the transmission of malaria. DDE [1-Chloro-2-[2,2-dichloro-1-(4-chlorophenyl)ethenyl]-benzene] is a common metabolite of DDT (Ssebugere et al., 2010; Yang et al., 2010). Environmental DDE originates from the metabolites of DDT resulting from aerobic biotic, abiotic, and photochemical degradation, as well as from technical-grade DDT contaminants (Thomas et al., 2008). DDE has been reported to be more persistent than DDT and can be detected in soil decades after the application of DDT (Thomas et al., 2008). According to the United States Geological Survey (USGS), p,p'-DDE content in America was 60\% in urban areas and 48\% in rural areas in 1999 (Thomas et al., 2008). As a potent androgen antagonist (Kelce et al., 1995), DDE has also been found to be the most abundant DDT component in sediments (Eganhouse \& Pontolillo, 2008), fish, and humans (Kamanavalli \& Ninnekar, 2004).

Dicofol [2,2,2-trichloro-1,1-bis(4-chlorophenyl)ethanol] is a non-systemic acaricide extensively used in 
controlling mites. Dicofol is usually synthesized from technical $p, p^{\prime}$-DDT. During synthesis reaction (Scheme 1), $p, p^{\prime}$-DDT is first chlorinated into Cl-DDT, and then hydrolyzed into dicofol (Qiu et al., 2005).

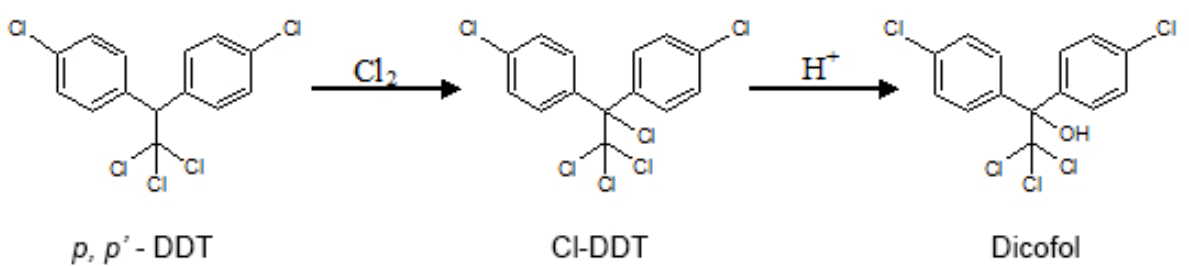

Scheme 1. Synthesis reaction of dicofol by $p, p^{\prime}-\mathrm{DDT}$

To date, China still produces 5000 tons to 6000 tons of DDT per year as raw and processed materials for dicofol production (Huang et al., 2007). Moreover, approximately 8770 tons of DDTs were released into the environment in China by dicofol-type DDT contamination from 1988 to 2002 (Qiu et al., 2005; Turgut et al., 2009).

Although biodegradation and anaerobic reductive dechlorination for remediating DDTs have been well studied (Li et al., 2010; You et al., 1996), investigations on aerobic oxidative degradation for remediating DDTs is limited. Chemical oxidation via persulfate oxidation activated by ferrous ion has been evaluated as an option for treating chlorinated organic contaminants, such as trichloroethylene (TCE; Liang et al., 2004a, 2004b; Liang et al., 2008); tetrachloroethylene, dichloroethylene, and dichloroethane (Abranovic et al., 2006); polychlorinated biphenyls and polycyclic aromatic hydrocarbons (Block et al., 2004); and lindane ( $\gamma$-HCH; Cao et al., 2008). Sulfate free radicals $\left(\mathrm{SO}_{4}^{-}\right)$can be formed rapidly through persulfate-ferrous ion reaction at ambient temperature $\left(20^{\circ} \mathrm{C}\right)$ (Liang et al., 2004a). These free radicals can potentially degrade organic contaminants within soil mass by in situ chemical oxidation. The stoichiometric reaction between persulfate and ferrous ion is shown in the following equations (Kolthoff et al., 1951):

$$
\begin{gathered}
\mathrm{Fe}^{2+}+\mathrm{S}_{2} \mathrm{O}_{8}{ }^{2-} \rightarrow \mathrm{Fe}^{3+}+\mathrm{SO}_{4}{ }^{-\cdot}+\mathrm{SO}_{4}{ }^{2-} \\
\mathrm{SO}_{4}{ }^{-\cdot}+\mathrm{Fe}^{2+} \rightarrow \mathrm{Fe}^{3+}+\mathrm{SO}_{4}{ }^{2-}
\end{gathered}
$$

The ratio of reaction between $\mathrm{S}_{2} \mathrm{O}_{8}{ }^{2-}$ and $\mathrm{Fe}^{2+}$ is dependent on the concentration of each reactant. When the reaction is near to stall, increasing the concentration of $\mathrm{Fe}^{2+}$ will accelerate the reaction shown in Equation (1). However, the target chlorinated organic contaminant and the excess $\mathrm{Fe}^{2+}$ will compete for $\mathrm{SO}_{4}^{-}$, as shown in Equation (2). Gradual addition of small quantities of $\mathrm{Fe}^{2+}$ is necessary to optimize $\mathrm{S}_{2} \mathrm{O}_{8}{ }^{2-}$ oxidative degradation of the target chlorinated organic contaminant and to control the reaction. To our knowledge, no $\mathrm{Fe}^{2+}$-activated persulfate oxidation technique for remediating DDT contamination in sediments has yet been reported.

The primary purpose of this study is to investigate the contamination caused by dicofol-type DDTs in a dicofol manufacturing factory in Tianjin, China and to evaluate the effectiveness of $\mathrm{Fe}^{2+}$-activated $\mathrm{S}_{2} \mathrm{O}_{8}{ }^{2-}$ oxidative degradation for DDTs $\left(p, p^{\prime}\right.$-DDE and $p, p^{\prime}$-DDT). In addition, the effects of various initial $\mathrm{Fe}^{2+}$ and $\mathrm{S}_{2} \mathrm{O}_{8}{ }^{2-}$ concentrations on DDT degradation in sediments at ambient temperature $\left(20^{\circ} \mathrm{C}\right)$ are also investigated.

\section{Materials and Methods}

\subsection{Chemicals}

Standard samples of $p, p^{\prime}$-DDT $\left[p, p^{\prime}\right.$-dichlorodiphenyltrichloroethane $]\left(>99.5 \%\right.$ purity) and $p, p^{\prime}$-DDE [1-Chloro-2-[2,2-dichloro-1-(4-chlorophenyl)ethenyl]-benzene] ( $>99.5 \%$ purity) were obtained from Dr. Ehrenstorfer $\mathrm{GmbH}$ (Augsburg, Germany). Sodium persulfate $\left(\mathrm{Na}_{2} \mathrm{~S}_{2} \mathrm{O}_{8} ;>99 \%\right.$ purity), ferrous sulfate $\left(\mathrm{FeSO}_{4} \cdot 7 \mathrm{H}_{2} \mathrm{O} ;>99 \%\right.$ purity), anhydrous sodium sulfate $\left(\mathrm{Na}_{2} \mathrm{SO}_{4} ;>99 \%\right.$ purity), and other chemical reagents were of analytical grade, as required. Super pure GC hexane was obtained from J\&K Chemical Ltd. (China). Sodium persulfate and ferrous ion solutions were prepared with $18 \mathrm{M} \Omega$ deionized water (Milli-Q ${ }^{\mathrm{TM}} 18 \mathrm{M} \Omega$ system, Millipore Corporation, MA, USA) before use. All pieces of glassware were washed twice with hexane prior to use. Serum bottles $(20 \mathrm{~mL})$ were used as batch reactors.

\subsection{Sediment Collection and Preparation}

Sediment samples were collected from Tianjin Renong Pharmaceutical Factory in China (Scheme 2). Sampling sites were highly contaminated by DDTs because of dicofol manufacturing before 2002 . The three sampling sites were the factory floor, sewage, and drainage ditch. Sediments were collected from $20 \mathrm{~cm}$ to $40 \mathrm{~cm}$ sections 
mainly composed of fine sand with silt. The vessels were filled with sediments and completely sealed. The sediments were air-dried and ground with mortar until they could pass through a $2.0 \mathrm{~mm}$ sieve. The DDTs in the samples were detected via gas chromatography with mass selective detection (Table 1). Sample no. 3 was selected as the object for the batch study because it is highly contaminated with $p, p^{\prime}$-DDE $\left(115.27 \mathrm{mg} \mathrm{kg}^{-1}\right)$ and $p, p^{\prime}$-DDT $\left(11.84 \mathrm{mg} \mathrm{kg}^{-1}\right)$. The soluble sulfate of sample no. 3 was $56.28 \mathrm{mg} \mathrm{kg}^{-1}$ and its $\mathrm{pH}$ was 7.7. In addition, small amounts of $p, p^{\prime}$-DDD and $o, p^{\prime}$-DDE were also detected in all samples. However, no attempt was made to quantify $p, p^{\prime}$-DDD and $o, p^{\prime}$-DDE because their concentrations were very low.

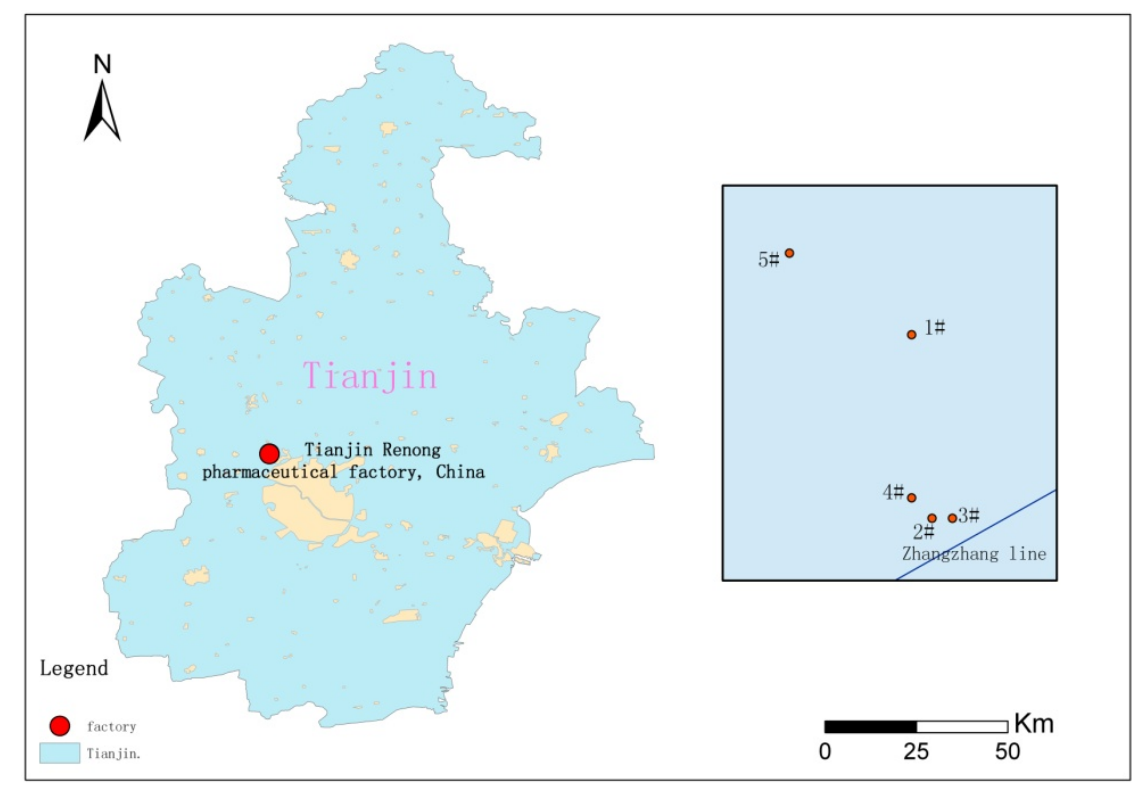

Scheme 2. The study area (Tianjin, China) and the sampling site (Tianjin Renong Pharmaceutical Factory)

\subsection{Batch Studies of DDT Oxidation Using Persulfate Activated by Ferrous Ion}

Two grams of air-dried sediment sample was added into the serum bottle with $4 \mathrm{~mL}$ deionized water and mixed completely. Two sets of experiments were performed to determine the following: (1) effect of $\mathrm{S}_{2} \mathrm{O}_{8}{ }^{2-}$ concentration on DDT degradation and (2) effect of $\mathrm{Fe}^{2+}$ concentration on DDT degradation. Six treatments were initiated for set (1): (i) control, (ii) $\mathrm{Na}_{2} \mathrm{~S}_{2} \mathrm{O}_{8}\left(10 \mathrm{mmol} \mathrm{L}^{-1}\right)+\mathrm{FeSO}_{4} \cdot 7 \mathrm{H}_{2} \mathrm{O}\left(30 \mathrm{mmol} \mathrm{L}^{-1}\right)$, (iii) $\mathrm{Na}_{2} \mathrm{~S}_{2} \mathrm{O}_{8}\left(20 \mathrm{mmol}^{-1}\right.$ $\left.\mathrm{L}^{-1}\right)+\mathrm{FeSO}_{4} \cdot 7 \mathrm{H}_{2} \mathrm{O}\left(30 \mathrm{mmol} \mathrm{L}^{-1}\right)$, (iv) $\mathrm{Na}_{2} \mathrm{~S}_{2} \mathrm{O}_{8}\left(40 \mathrm{mmol} \mathrm{L}^{-1}\right)+\mathrm{FeSO}_{4} \cdot 7 \mathrm{H}_{2} \mathrm{O}\left(30 \mathrm{mmol} \mathrm{L}^{-1}\right)$, (v) $\mathrm{Na}_{2} \mathrm{~S}_{2} \mathrm{O}_{8}(60$

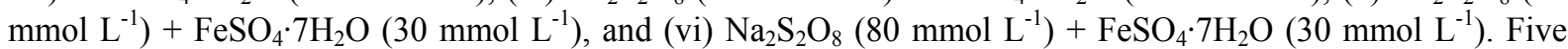
treatments were initiated for set (2): (i) control, (ii) $\mathrm{FeSO}_{4} \cdot 7 \mathrm{H}_{2} \mathrm{O}\left(10 \mathrm{mmol} \mathrm{L}^{-1}\right)+\mathrm{Na}_{2} \mathrm{~S}_{2} \mathrm{O}_{8}\left(60 \mathrm{mmol} \mathrm{L}^{-1}\right)$, (iii) $\mathrm{FeSO}_{4} \cdot 7 \mathrm{H}_{2} \mathrm{O}\left(20 \mathrm{mmol} \mathrm{L}^{-1}\right)+\mathrm{Na}_{2} \mathrm{~S}_{2} \mathrm{O}_{8}\left(60 \mathrm{mmol} \mathrm{L}^{-1}\right)$, (iv) $\mathrm{FeSO}_{4} \cdot 7 \mathrm{H}_{2} \mathrm{O}(40 \mathrm{mmol} \mathrm{L}-1)+\mathrm{Na}_{2} \mathrm{~S}_{2} \mathrm{O}_{8}\left(60 \mathrm{mmol} \mathrm{L}^{-1}\right)$, and (v) $\mathrm{FeSO}_{4} \cdot 7 \mathrm{H}_{2} \mathrm{O}\left(50 \mathrm{mmol} \mathrm{L}^{-1}\right)+\mathrm{Na}_{2} \mathrm{~S}_{2} \mathrm{O}_{8}\left(60 \mathrm{mmol} \mathrm{L}^{-1}\right)$. For each set of experiment, $1 \mathrm{~mL}$ reagent solution was added in the following order: (1) sodium persulfate and (2) ferrous ion (one-fifth every $5 \mathrm{~min}$ ) (Liang et al., 2004a). Afterwards, the sediments and solutions were vortex-mixed and incubated at ambient temperature $\left(20^{\circ} \mathrm{C}\right)$. Sampling and detection of the remaining amounts of DDTs were conducted at $0,1,2,3$, and $4 \mathrm{~h}$. The concentration of sulfate in the supernatant was detected by ion chromatography at $4 \mathrm{~h}$.

\subsection{Extraction and Analysis of DDTs}

The DDTs in the sediments were extracted using the ultrasonic extraction method. Hexane $(10 \mathrm{~mL})$ was added to the serum bottles containing the sediments. The bottles were then sonicated for 30 min in $6 \mathrm{~L}$ water in an ultrasonic bath (Soniclean, Australia) to ensure particle and solvent mixing (Thangavadivel et al., 2011). Furthermore, the contents were vortex-mixed and the solvent with DDTs was separated and passed through a funnel filled with $2.0 \mathrm{~g}$ anhydrous sodium sulfate $\left(\mathrm{Na}_{2} \mathrm{SO}_{4}\right)$ to eliminate the remaining water in the samples (Hussen et al., 2006). Then, the extraction solvent with DDTs was evaporated to $2.0 \mathrm{~mL}$ using nitrogen gas.

The DDTs were analyzed by an Agilent 7890A gas chromatograph (Agilent Technologies, CA, USA) equipped with an Agilent 5975C mass selective detector (Agilent Technologies, CA, USA). The column used was HP-5MS, $30.00 \mathrm{~m} \times 0.25 \mathrm{~mm}$ id with a film thickness of $0.25 \mu \mathrm{m}$. The injector temperature was $250{ }^{\circ} \mathrm{C}$ and the 
helium gas flow rate was $1.0 \mathrm{~mL} \mathrm{~min}$. The column temperature was initially set to $40{ }^{\circ} \mathrm{C}$ for $1 \mathrm{~min}$, and then later increased at a rate of $30^{\circ} \mathrm{C} \mathrm{min}^{-1}$ to $130^{\circ} \mathrm{C} \mathrm{min}^{-1}$. Afterwards, column temperature was switched to a rate of $5{ }^{\circ} \mathrm{C} \mathrm{min}{ }^{-1}$ to $160{ }^{\circ} \mathrm{C} \mathrm{min}{ }^{-1}$ for $6 \mathrm{~min}$, and then, to a rate of $10{ }^{\circ} \mathrm{C} \mathrm{min}^{-1}$ to $190{ }^{\circ} \mathrm{C}$ for $3 \mathrm{~min}$. Finally, the temperature was switched to a rate of $20^{\circ} \mathrm{C} \min ^{-1}$ to $300{ }^{\circ} \mathrm{C}$ and maintained isothermally for 2 min (Manirakiza et al., 2000). The injection volume was $1.0 \mu \mathrm{L}$ in a splitless mode.

\subsection{Analysis of the Sulfate in the Supernatant}

According to Equations (1) and (2), persulfate will decompose into sulfate during reactions activated by ferrous ion. To evaluate the amount of decomposed persulfate, the concentration of supernatant sulfate was determined by ion chromatography. After $4 \mathrm{~h}$ reaction, $0.5 \mathrm{~mL}$ supernatant was passed through a $0.45 \mu \mathrm{m}$ filter to eliminate impurities which may interfere with ion chromatography. The ion chromatography system, Dionex Ionpac AS14 column $(4.6 \mathrm{~mm} \times 3100.0 \mathrm{~mm}$; Thermo Scientific, CA, USA), comprises a GP50 gradient pump, a column oven LC25, and an electrochemical detector ED50. Elution buffer was made of $3.5 \mathrm{mM}$ sodium bicarbonate and 1.0 $\mathrm{mM}$ sodium carbonate. The flow ratio was $1.2 \mathrm{~mL} \mathrm{~min}^{-1}$.

\section{Results and Discussion}

\subsection{Assessment of DDT Contamination in Sampling Sites}

Although the sampling site was a dicofol manufacturing factory which closed in 2002, no dicofol was detected in the samples because this pesticide is highly degradable in natural environments. However, DDT contamination remains serious even after nine years of production cessation. Dicofol impurity was proposed to possibly contribute to DDTs in the environment. This hypothesis was supported by the investigation of air samples collected over Taihu Lake, China during the summer of 2002, where very high concentrations of DDTs were found to be related to dicofol applications (Qiu et al., 2004), thus suggesting that dicofol is a possible source of DDTs which may constantly evaporate from soil to air.

According to the guidelines of the Chinese Environmental Quality Standard for Soil (GB15618-1995), the quality of soil can be classified as: with background pollution (grade I), low pollution (grade II), and high pollution (grade III). All three sampling sites were highly contaminated by DDTs, as shown in Table 1. $p, p^{\prime}$-DDE and $p, p^{\prime}$-DDT were the main DDT components and their concentration $\left(1 \mathrm{mg} \mathrm{kg}^{-1}\right)$ was much higher than that of grade III soil. Moreover, $p, p^{\prime}$-DDE concentration was higher than $p, p^{\prime}$-DDT concentration in all samples. The results confirmed previous findings that DDE is the most abundant DDT component in soil and sediments (Guo et al., 2009), and is hardly degraded compared with other DDT components (Thomas et al., 2008; de la Cal et al., 2008). Further investigations and an effective remediation option for dicofol-type DDT contamination are recommended.

Table 1. Concentrations of DDTs in samples obtained from the three sampling sites

\begin{tabular}{llcc}
\hline Station & Orientation & $\begin{array}{c}p, p^{\prime}-\mathrm{DDT}\left(\mathrm{mg} \mathrm{kg}^{-1}\right) \\
(\mathrm{Mean} \pm \mathrm{SE})\end{array}$ & $\begin{array}{c}p, p^{\prime}-\mathrm{DDE}\left(\mathrm{mg} \mathrm{kg}^{-1}\right) \\
(\mathrm{Mean} \pm \mathrm{SE})\end{array}$ \\
\hline No. 1 & $\mathrm{~N}: 39^{\circ} 14^{\prime} 26.1^{\prime \prime}$ & $4.38 \pm 0.45$ & $22.99 \pm 1.21$ \\
& E: $117^{\circ} 06^{\prime} 33.7^{\prime \prime}$ & & \\
No. 2 & $\mathrm{~N}: 39^{\circ} 14^{\prime} 23 "$, & $10.27 \pm 1.54$ & $14.34 \pm 1.61$ \\
& E: $117^{\circ} 06^{\prime} 34.14^{\prime \prime}$ & & \\
No. 3 & $\begin{array}{l}\mathrm{N}: 39^{\circ} 14^{\prime} 23.3 ", \\
\text { E: } 117^{\circ} 06^{\prime} 33.7^{\prime \prime}\end{array}$ & $11.84 \pm 0.97$ & $115.27 \pm 7.52$ \\
\hline
\end{tabular}

The samples were collected in 2010. Mean \pm SE values $\left(\mathrm{mg} \mathrm{kg}^{-1}\right)$ are shown $(\mathrm{n}=3)$. Means are significantly different (one-way ANOVA: $\mathrm{p}<0.05$ ).

\subsection{Influence of $\mathrm{S}_{2} \mathrm{O}_{8}{ }^{2-}$ Concentration on DDT Degradation}

To investigate the effect of persulfate contents on DDT degradation at $\mathrm{Fe}^{2+}$ concentration of $30 \mathrm{mM}$ at ambient temperature $\left(20{ }^{\circ} \mathrm{C}\right)$, different concentrations of persulfate were used. For all $\mathrm{S}_{2} \mathrm{O}_{8}{ }^{2-} / \mathrm{Fe}^{2+}$ molar ratios, DDT degradation and persulfate decomposition (represented by sulfate formation) were observed (Figures 1 and 2). DDT degradation occurred almost instantaneously and stabilized because of the high reactive activity and unstability of $\mathrm{SO}_{4}^{-}$generated from $\mathrm{S}_{2} \mathrm{O}_{8}{ }^{2-}-\mathrm{Fe}^{2+}$ reaction. For $p, p^{\prime}$-DDE, the remaining ratios after $4 \mathrm{~h}$ decreased 
from $71 \%$ to $40 \%$ at $\mathrm{S}_{2} \mathrm{O}_{8}{ }^{2-} / \mathrm{Fe}^{2+}$ molar ratios of $10 / 30$ to $80 / 30$, respectively (Table 2 ). An increase in persulfate concentrations when $\mathrm{Fe}^{2+}$ level is $30 \mathrm{mM}$ resulted in increased DDT degradation. However, an insignificant increase in DDT degradation was observed when $\mathrm{S}_{2} \mathrm{O}_{8}{ }^{2-} / \mathrm{Fe}^{2+}$ molar ratio was higher than 60/30. The $p, p^{\prime}$-DDT remaining ratios after $4 \mathrm{~h}$ were $23 \%, 19 \%, 25 \%, 4 \%$, and $5 \%$ at $\mathrm{S}_{2} \mathrm{O}_{8}{ }^{2-} / \mathrm{Fe}^{2+}$ molar ratios of $10 / 30,20 / 30,40 / 30$, $60 / 30$, and $80 / 30$, respectively (Table 2). The influence of various persulfate concentrations on the degradation time course of DDTs $\left(p, p^{\prime}\right.$-DDE and $p, p^{\prime}$-DDT) (Figure 1) indicated that total degradation ratios (in ascending order) were $10 / 30<20 / 30<40 / 30<60 / 30<80 / 30$. Increasing the amount of persulfate content did result in an increase in sulfate formation and a proportional increase in DDT degradation except for the 80/30 $\mathrm{S}_{2} \mathrm{O}_{8}{ }^{2-} / \mathrm{Fe}^{2+}$ treatment (Figure 2). The concentration amounts of sulfate originating from the decomposition of persulfate were $10.04,10.14,10.28,12.64$, and $12.83 \mathrm{mg} \mathrm{g}^{-1}$ at $\mathrm{S}_{2} \mathrm{O}_{8}{ }^{2-} / \mathrm{Fe}^{2+}$ molar ratios of $10 / 30,20 / 30,40 / 30,60 / 30$, and 80/30, respectively. The amount of DDT degradation were 43, 52, 71, 89, and $91 \mu \mathrm{g} \mathrm{g}{ }^{-1}$ at $\mathrm{S}_{2} \mathrm{O}_{8}{ }^{2-} / \mathrm{Fe}^{2+}$ molar ratios of $10 / 30,20 / 30,40 / 30,60 / 30$, and $80 / 30$, respectively. The $\mathrm{S}_{2} \mathrm{O}_{8}{ }^{2-} / \mathrm{Fe}^{2+}$ molar ratio of $60 / 30$ is the most effective and economical proportion. The observed optimal reaction ratio of $\mathrm{S}_{2} \mathrm{O}_{8}{ }^{2-} / \mathrm{Fe}^{2+}$ is greater than the theoretical stoichiometric ratio of 1:1 according to Equation (1). Persulfate anions were depleted by several reactions, such as organic substance oxidation, apart from those activated by $\mathrm{Fe}^{2+}$ (Kolthoff et al., 1951). The result was similar to that reported by Liang et al. (2004a) who suggested that the $\mathrm{S}_{2} \mathrm{O}_{8}{ }^{2-} / \mathrm{Fe}^{2+}$ molar ratio of $40 / 30$ is the most effective proportion for TCE degradation in aqueous systems, and that beyond this ratio, adding persulfate only resulted in an insignificant increase in TCE degradation. In this study, an excess concentration of persulfate was necessary because persulfate was consumed by sediment materials. As for $\mathrm{S}_{2} \mathrm{O}_{8}{ }^{2-} / \mathrm{Fe}^{2+}$ molar ratios of $10 / 30$, $20 / 30$, and $40 / 30$, the initial persulfate concentrations were insufficient when considering the stoichiometric ratio of reactions between persulfate and ferrous ions. Without adding persulfate and ferrous ion, no DDT degradation was observed for $4 \mathrm{~h}$.

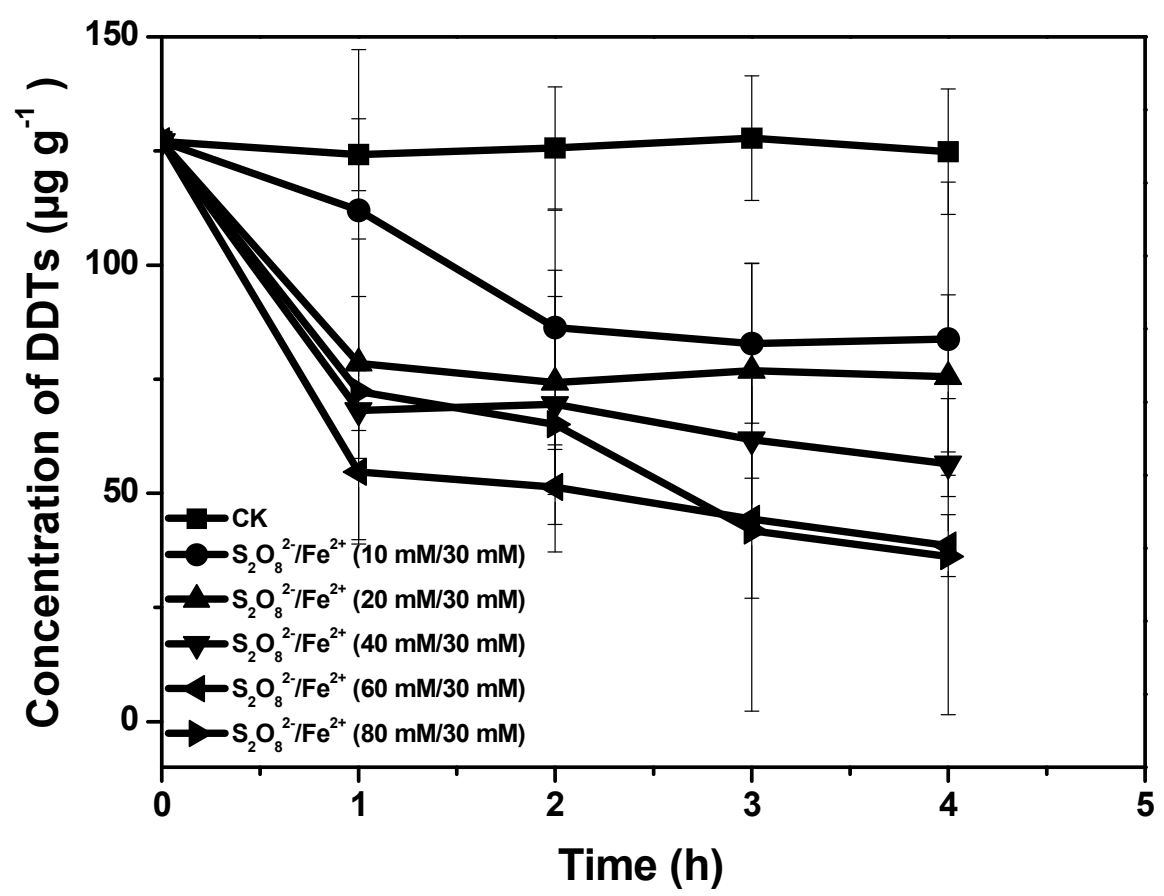

Figure 1. Dynamics of DDT degradation with different persulfate concentrations 


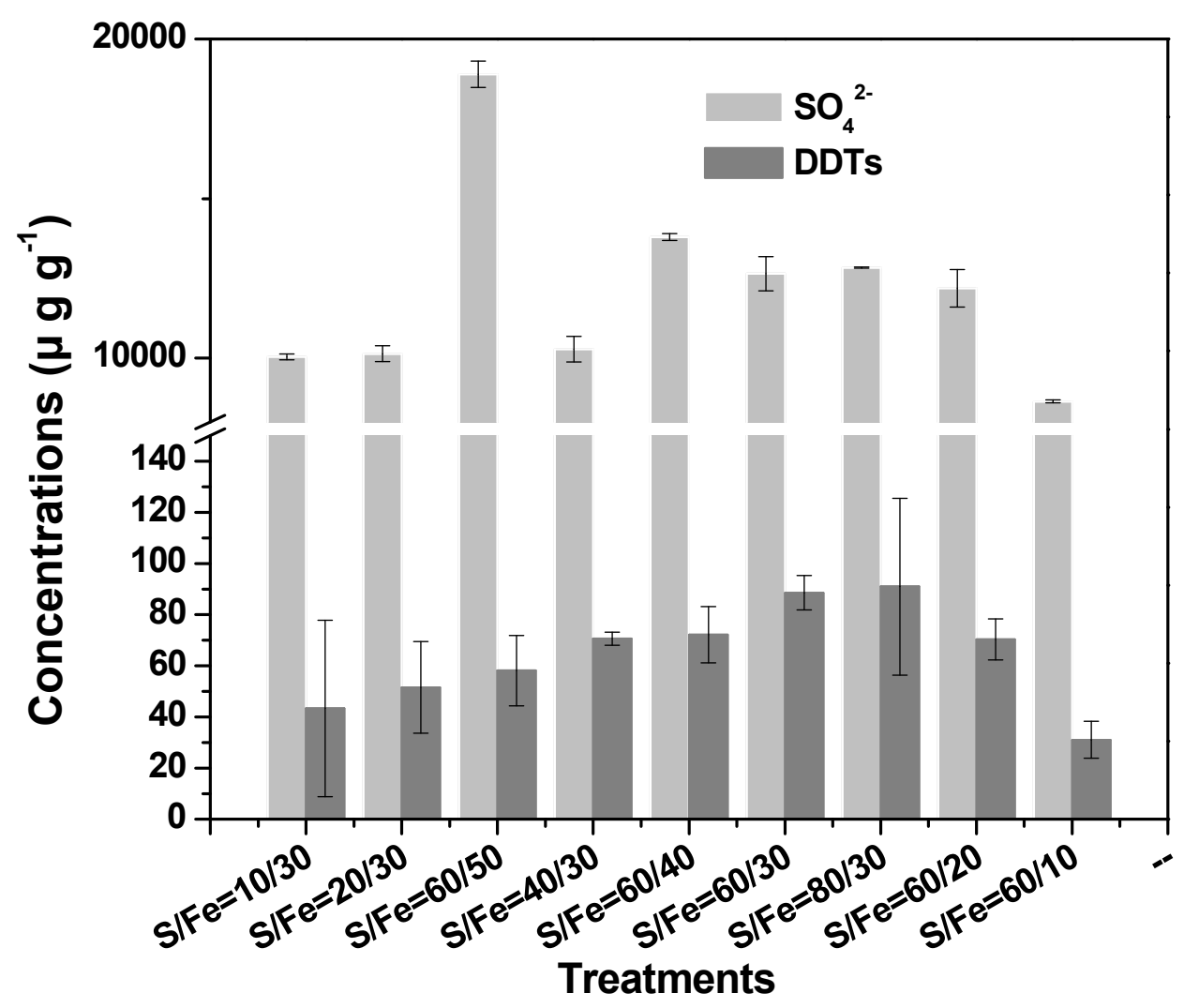

Figure 2. DDT degradation and sulfate formed by persulfate decomposition after $4 \mathrm{~h}$

Table 2. The influence of different persulfate concentrations on the degradation of (A) DDE and (B) DDT

\begin{tabular}{ccc}
\hline \multirow{2}{*}{$\mathrm{S}_{2} \mathrm{O}_{8}{ }^{2-} / \mathrm{Fe}^{2+}$ molar ratio } & \multicolumn{2}{c}{ Degradation ratio $\left(\mathrm{C}_{\mathrm{t}} / \mathrm{C}_{0} \%\right)$} \\
\cline { 2 - 3 } & $\mathrm{DDE}(\mathrm{Mean} \pm \mathrm{SD})$ & $\mathrm{DDT}(\mathrm{Mean} \pm \mathrm{SD})$ \\
\hline $10 / 30$ & $29.06 \pm 11.02$ & $76.95 \pm 29.30$ \\
$20 / 30$ & $36.21 \pm 9.20$ & $80.84 \pm 23.00$ \\
$40 / 30$ & $50.67 \pm 2.55$ & $74.93 \pm 3.17$ \\
$60 / 30$ & $64.09 \pm 15.64$ & $95.77 \pm 20.35$ \\
$80 / 30$ & $39.94 \pm 35.14$ & $94.66 \pm 86.32$ \\
\hline
\end{tabular}

\subsection{The Influence of $\mathrm{Fe}^{2+}$ Concentration on DDT Degradation}

To further elucidate the effect of available ferrous ion at ambient temperature $\left(20{ }^{\circ} \mathrm{C}\right)$ on the degradation of DDTs, ferrous ion was added in one-fifth increments to the reaction bottles containing $\mathrm{S}_{2} \mathrm{O}_{8}{ }^{2-}$ concentration of 60 $\mathrm{mM}$ at $5 \mathrm{~min}$ intervals. Figure 3 shows the effect of different $\mathrm{Fe}^{2+}$ concentrations on DDT degradation and persulfate decomposition. DDT degradation and persulfate decomposition (indicated by sulfate formation) were observed in all $\mathrm{S}_{2} \mathrm{O}_{8}{ }^{2-} / \mathrm{Fe}^{2+}$ molar ratios. After five successive additions of $\mathrm{Fe}^{2+}$, the initial $\mathrm{S}_{2} \mathrm{O}_{8}{ }^{2-} / \mathrm{Fe}^{2+}$ molar ratios were $60 / 10,60 / 20,60 / 30,60 / 40$, and 60/50. The remaining $p, p^{\prime}$-DDE after $4 \mathrm{~h}$ were $100 \%, 63 \%, 36 \%$, $60 \%$, and $59 \%$, respectively (Table 3 ). In the case of the $60 / 10 \mathrm{~S}_{2} \mathrm{O}_{8}{ }^{2-} / \mathrm{Fe}^{2+}$ molar ratio, $p, p^{\prime}$-DDE degradation was insignificant because the concentration of $\mathrm{Fe}^{2+}$ was insufficient. Increasing $\mathrm{Fe}^{2+}$ concentration from a $\mathrm{S}_{2} \mathrm{O}_{8}{ }^{2-} / \mathrm{Fe}^{2+}$ molar ratio of $60 / 10$ to $60 / 30$ resulted in approximately $64 \%$ increase in $p, p^{\prime}$-DDE degradation. Theoretically, increasing $\mathrm{Fe}^{2+}$ concentration would produce more $\mathrm{SO}_{4}{ }^{-}$which could promote DDT degradation. However, $p, p^{\prime}$-DDE degradation decreased when $\mathrm{S}_{2} \mathrm{O}_{8}{ }^{2-} / \mathrm{Fe}^{2+}$ molar ratio was higher than 60/30. Similar phenomena have been reported by other researchers (Kislenko et al., 1995; Liang et al., 2004a). The possible consumption of sulfate free radicals may result from reactions with $\mathrm{H}_{2} \mathrm{O}, \mathrm{S}_{2} \mathrm{O}_{8}{ }^{2-}$, and excess $\mathrm{Fe}^{2+}$ (Kolthoff et al., 
1951; Mcelroy \& Waygood, 1990), as shown in Equations (2), (3), and (4).

$$
\begin{gathered}
\mathrm{SO}_{4}^{-}+\mathrm{H}_{2} \mathrm{O} \rightarrow \mathrm{OH}+\mathrm{HSO}_{4}^{-} \cdot \\
\mathrm{SO}_{4}^{-\cdot}+\mathrm{S}_{2} \mathrm{O}_{8}{ }^{2-} \rightarrow \mathrm{SO}_{4}{ }^{2-}+\mathrm{S}_{2} \mathrm{O}_{8}^{-}
\end{gathered}
$$

The remaining $p, p^{\prime}$-DDT after $4 \mathrm{~h}$ were $4.92 \%, 3.29 \%, 4.23 \%, 6.07 \%$, and $2.29 \%$ at $\mathrm{S}_{2} \mathrm{O}_{8}{ }^{2-} / \mathrm{Fe}^{2+}$ molar ratios of $60 / 10,60 / 20,60 / 30,60 / 40$, and 60/50, respectively (Table 3). The rates of $p, p^{\prime}$-DDT degradation were all significant whether $\mathrm{Fe}^{2+}$ content was sufficient or insufficient. $\mathrm{Fe}^{2+}$ has also been reported to result in significant $p, p^{\prime}$-DDT reductive degradation (Li et al., 2010). The observed $\mathrm{S}_{2} \mathrm{O}_{8}{ }^{2-}-\mathrm{Fe}^{2+}$ system in this study showed that the competition for $\mathrm{SO}_{4}^{-}$between excess $\mathrm{Fe}^{2+}$ and DDTs was significant (Figure 2). Further increases in $\mathrm{Fe}^{2+}$ contents resulted in proportional increases in persulfate decomposition but not in DDT degradation (Figure 2). The sulfate obtained from the decomposition of persulfate, accompanied by increasing $\mathrm{Fe}^{2+}$ amounts, were 8.64, 12.19, 12.64, 13.79, and $18.89 \mathrm{mg} \mathrm{g}^{-1}$ at $\mathrm{S}_{2} \mathrm{O}_{8}{ }^{2-} / \mathrm{Fe}^{2+}$ molar ratios of 60/10, 60/20, 60/30, 60/40, and 60/50, respectively. The rates of DDT degradation were $31,70,89,72$, and $69 \mu \mathrm{g} \mathrm{g}^{-1}$ at $\mathrm{S}_{2} \mathrm{O}_{8}{ }^{2-} / \mathrm{Fe}^{2+}$ molar ratios of $60 / 10,60 / 20,60 / 30,60 / 40$, and 60/50, respectively. In this case, the rates of DDT degradation were not in agreement with the sulfate concentrations, thus indicating that high amounts of $\mathrm{Fe}^{2+}$ resulted in a competition for $\mathrm{SO}_{4}{ }^{-}$between excess $\mathrm{Fe}^{2+}$ and DDTs at $\mathrm{S}_{2} \mathrm{O}_{8}{ }^{2-} / \mathrm{Fe}^{2+}$ molar ratios less than 60/30. Moreover, the degradation time course of DDTs ( $p, p^{\prime}$-DDE and $p, p^{\prime}$-DDT) (Figure 3 ) indicated that total degradation ratios (in ascending order) were $60 / 10<60 / 50<60 / 20<60 / 40<60 / 30$. Therefore, sulfate free radicals formed through ferrous-ion activation are capable of effective DDT oxidative degradation, and that the optimum molar ratio for $\mathrm{S}_{2} \mathrm{O}_{8}{ }^{2-} / \mathrm{Fe}^{2+}$ was 60/30.

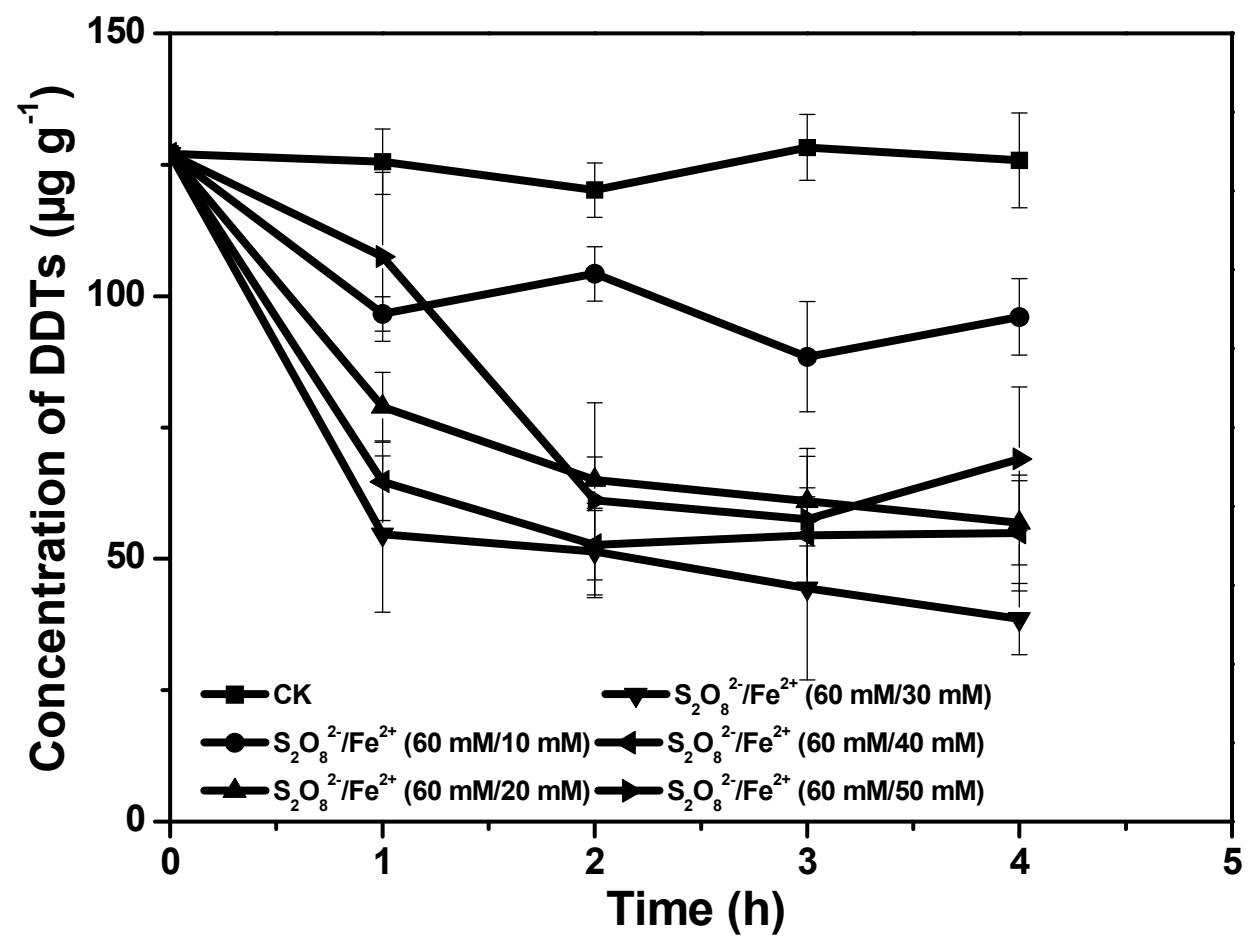

Figure 3. Time course of DDT degradation with different concentrations of ferrous ion 
Table 3. Influence of different ferrous ion concentrations on the degradation of (A) DDE and (B) DDT

\begin{tabular}{ccc}
\hline \multirow{2}{*}{$\mathrm{S}_{2} \mathrm{O}_{8}{ }^{2-} / \mathrm{Fe}^{2+}$ molar ratio } & \multicolumn{2}{c}{ Degradation ratio $\left(\mathrm{C}_{\mathrm{t}} / \mathrm{C}_{0} \%\right)$} \\
\cline { 2 - 3 } & $\mathrm{DDE}($ Mean $\pm \mathrm{SD})$ & $\mathrm{DDT}(\mathrm{Mean} \pm \mathrm{SD})$ \\
\hline $60 / 10$ & 0 & $95.08 \pm 7.56$ \\
$60 / 20$ & $37.37 \pm 6.21$ & $96.72 \pm 13.20$ \\
$60 / 30$ & $64.09 \pm 13.90$ & $95.77 \pm 21.21$ \\
$60 / 40$ & $39.98 \pm 8.07$ & $93.93 \pm 16.98$ \\
$60 / 50$ & $40.14 \pm 9.96$ & $97.71 \pm 13.32$ \\
\hline
\end{tabular}

\section{Conclusions}

The assessment of the site for a dicofol manufacturing factory showed serious DDT ( $p, p^{\prime}$-DDE and $p, p^{\prime}$-DDT) contamination in sediments. DDT degradation and persulfate decomposition were observed by calculating the amount of ferrous ion and persulfate at ambient temperature $\left(20^{\circ} \mathrm{C}\right)$. This study demonstrated that sulfate free radicals formed by ferrous ion activation are capable of degrading DDTs in sediments. Total DDT degradation ratios at $\mathrm{S}_{2} \mathrm{O}_{8}{ }^{2-} / \mathrm{Fe}^{2+}$ molar ratios of $31,43,52,69,70,71,72,89$, and $91 \mu \mathrm{g} \mathrm{g}^{-1}$ were $60 / 10<10 / 30<20 / 30<$ $60 / 50<60 / 20<40 / 30<60 / 40<60 / 30<80 / 30$, respectively. However, ferrous ion would react with $\mathrm{SO}_{4}{ }^{-}$and DDT degradation efficiency would decrease if ferrous ion contents became excessive. Further increases in persulfate concentration beyond an $\mathrm{S}_{2} \mathrm{O}_{8}{ }^{2-} / \mathrm{Fe}^{2+}$ molar ratio of $60 / 30$ resulted in insignificant increases in DDT degradation. Thus, an $\mathrm{S}_{2} \mathrm{O}_{8}{ }^{2-} / \mathrm{Fe}^{2+}$ molar ratio of $60 / 30$ was the most effective and economical proportion. This result indicated that a slow and steady production of free radicals is most desirable, and that $\mathrm{Fe}^{2+}$ availability plays an important role in controlling persulfate reactions activated by ferrous ion. $\mathrm{Fe}^{2+}$-activated persulfate may be significant in developing an effective and environment friendly remediation option for DDT-contaminated sediments and soils. However, further work is necessary to determine how practical applications can be accomplished.

\section{Acknowledgments}

This research was jointly supported by the National Science Foundation of China (Grant No. 20777092) and the Ministry of Science and Technology of China (2007CB407304).

\section{References}

Abranovic, D. J., Brown, D., \& Chemburkar, A. (2006). Persulfate stability is limiting factor for ISCO in fine-grained, iron-rich media, In Proceedings of the Fifth International Conference on Remediation of Chlorinated and Recalcitrant Compounds, Monterey, CA. 22-25 May. Columbus, Ohio: Battelle Press, D-75.

Bettinetti, R., Quadroni, S., Galassi, S., Bacchetta, R., Bonardi, L., \& Vailati, G. (2008). Is meltwater from Alpine glaciers a secondary DDT source for lakes? Chemosphere, 73(7), 1027-1031. http://dx.doi.org/10.1016/j.chemosphere.2008.08.017

Block, P. A, Brown, R. A., \& Robinson, D. (2004). Novel activation technologies for sodium persulfate in situ chemical oxidation, In Proceedings of the Fourth International Conference on Remediation of Chlorinated and Recalcitrant Compounds, Monterey, CA. Gavaskar, A. R., \& Chen, A. S. C. (Eds.). Columbus, Ohio: Battelle Press.

Cao, J., Zhang, W.-X., Brown, D. G., \& Sethi, D. (2008). Oxidation of lindane with Fe (II)-activated sodium persulfate. Environmental Engineering Science, 25(2), 221-228. http://dx.doi.org/10.1089/ees.2006.0244

De la Cal, A., Eljarrat, E., Raldúa, D., Durán, C., \& Barceló, D. (2008). Spatial variation of DDT and its metabolites in fish and sediment from Cinca River, a tributary of Ebro River (Spain). Chemosphere, 70(7), 1182-1189. http://dx.doi.org/10.1016/j.chemosphere.2007.08.036

Eganhouse, R. P., \& Pontolillo, J. (2008). DDE in sediments of the Palos Verdes Shelf, California: In situ transformation rates and geochemical fate. Environmental Science \& Technology, 42(17), 6392-6398. 
http://dx.doi.org/10.1021/es7029619

Guo, Y., Yu, H.-Y., \& Zeng, E. Y. (2009). Occurrence, source diagnosis, and biological effect assessment of DDT and its metabolites in various environmental compartments of the Pearl River Delta, South China: A review. Environmental Pollution, 157(6), 1753-1763. http://dx.doi.org/10.1016/j.envpol.2008.12.026

Huang, Y., Zhao, X., \& Luan, S. (2007). Uptake and biodegradation of DDT by 4 ectomycorrhizal fungi. Science of the Total Environment, 385(1), 235-241. http://dx.doi.org/10.1016/j.scitotenv.2007.04.023

Hussen, A., Westbom, R., Megersa, N., Retta, N., Mathiasson, L., \& Björklund, E. (2006). Optimisation of pressurised liquid extraction for the determination of $\mathrm{p}, \mathrm{p}^{\prime}$-DDT and $\mathrm{p}, \mathrm{p}^{\prime}$-DDE in aged contaminated Ethiopian soils. Analytical and bioanalytical chemistry, 386(5), 1525-1533. http://dx.doi.org/10.1007/s00216-006-0667-z

Kamanavalli, C. M., \& Ninnekar, H. Z. (2004). Biodegradation of DDT by a Pseudomonas species. Current microbiology, 48(1), 10-13. http://dx.doi.org/10.1007/s00284-003-4053-1

Kelce, W. R., Stone, C. R., Laws, S. C., Gray, L. E., Kemppainen, J. A., \& Wilson, E. M. (1995). Persistent DDT metabolite $\mathrm{p}, \mathrm{p}^{\prime}$-DDE is a potent androgen receptor antagonist. Nature, 375, 581-585. http://dx.doi.org/10.1038/375581a0

Kislenko, V. N., Berlin, A. A., \& Litovchenko, N. V. (1995). Kinetics of Glucose Oxidation with Persulfate Ions, Catalyzed by Iron Salts. Russian Journal of General Chemistry Part, 657, 1092-1096.

Kolthoff, I., Medalia, A., \& Raaen, H. P. (1951). The Reaction between Ferrous Iron and Peroxides. IV. Reaction with Potassium Persulfate1a. Journal of the American Chemical Society, 73(4), 1733-1739. http://dx.doi.org/10.1021/ja01148a089

Li, F., Li, X., Zhou, S., Zhuang, L., Cao, F., Huang, D., ... Feng, C. (2010). Enhanced reductive dechlorination of DDT in an anaerobic system of dissimilatory iron-reducing bacteria and iron oxide. Environmental Pollution, 158(5), 1733-1740. http://dx.doi.org/10.1016/j.envpol.2009.11.020

Liang, C., Bruell, C. J., Marley, M. C., \& Sperry, K. L. (2004a). Persulfate oxidation for in situ remediation of TCE. I. Activated by ferrous ion with and without a persulfate-thiosulfate redox couple. Chemosphere, 55(9), 1213-1223. http://dx.doi.org/10.1016/j.chemosphere.2004.01.029

Liang, C., Bruell, C. J., Marley, M. C., \& Sperry, K. L. (2004b). Persulfate oxidation for in situ remediation of TCE. II. Activated by chelated ferrous ion. Chemosphere, 55(9), 1225-1233. http://dx.doi.org/10.1016/j.chemosphere.2004.01.030

Liang, C., Lee, I., Hsu, I., Liang, C.-P., \& Lin, Y.-L. (2008). Persulfate oxidation of trichloroethylene with and without iron activation in porous media. Chemosphere, 70(3), 426-435. http://dx.doi.org/10.1016/j.chemosphere.2007.06.077

Manirakiza, P., Covaci, A., \& Schepens, P. (2000). Single step clean-up and GC-MS quantification of organochlorine pesticide residues in spice powder. Chromatographia, 52(11), 787-790. http://dx.doi.org/10.1007/BF02491005

Mcelroy, W. J., \& Waygood, S. J. (1990). Kinetics of the reactions of the $\mathrm{SO}_{4}^{-}$radical with $\mathrm{SO}_{4}{ }^{-}, \mathrm{S}_{2} \mathrm{O}_{8}{ }^{2-}, \mathrm{H}_{2} \mathrm{O}$ and $\mathrm{Fe}^{2+}$. Journal of the Chemical Society, Faraday Transactions, 86, 2557-2564.

Qiu, X., Zhu, T., Li, J., Pan, H., Li, Q., Miao, G., \& Gong, J. (2004). Organochlorine pesticides in the air around the Taihu Lake, China. Environmental Science \& Technology, 38(5), 1368-1374. http://dx.doi.org/10.1021/es035052d

Qiu, X., Zhu, T., Yao, B., Hu, J., \& Hu, S. (2005). Contribution of dicofol to the current DDT pollution in China. Environmental Science \& Technology, 39(12), 4385-4390. http://dx.doi.org/10.1021/es050342a

Ssebugere, P., Wasswa, J., Mbabazi, J., Nyanzi, S. A., Kiremire, B. T., \& Marco, J. A. (2010). Organochlorine pesticides in soils from south-western Uganda. Chemosphere, 78(10), 1250-1255. http://dx.doi.org/10.1016/j.chemosphere.2009.12.039

Thangavadivel, K., Megharaj, M., Smart, R. S. C., Lesniewski, P. J., Bates, D., \& Naidu, R. (2011). Ultrasonic Enhanced Desorption of DDT from Contaminated Soils. Water, Air, \& Soil Pollution, 217(1), 115-125. http://dx.doi.org/10.1007/s11270-010-0572-0

Thomas, J. E., Ou, L. T., \& Al-Agely, A. (2008). DDE Remediation and Degradation, In D. M. Whitacre. (Ed.), Reviews of Environmental Contamination and Toxicology (pp. 55-69). Gainesville, FL 32611, U.S.A. 
Turgut, C., Gokbulut, C., \& Cutright, T. J. (2009). Contents and sources of DDT impurities in dicofol formulations in Turkey. Environmental Science and Pollution Research, 16(2), 214-217. http://dx.doi.org/10.1007/s11356-008-0083-3

Yang, L., Xia, X., Liu, S., \& Bu, Q. (2010). Distribution and sources of DDTs in urban soils with six types of land use in Beijing, China. Journal of Hazardous Materials, 174(1), 100-107. http://dx.doi.org/10.1016/j.jhazmat.2009.09.022

Yao, F. X., Jiang, X., Yu, G. F., Wang, F., \& Bian, Y. R. (2006). Evaluation of accelerated dechlorination of p,p'-DDT in acidic paddy soil. Chemosphere, 628-633. http://dx.doi.org/10.1016/j.chemosphere.2005.10.066

You, G., Sayles, G. D., Kupferle, M. J., Kim, I. S., \& Bishop, P. L. (1996). Anaerobic DDT biotransformation: enhancement by application of surfactants and low oxidation reduction potential. Chemosphere, 32(11), 2269-2284. http://dx.doi.org/10.1016/0045-6535(96)00121-X

Zitko, V. (2003). Chlorinated Pesticides: Aldrin, DDT, Endrin, Dieldrin, Mirex. In H. Fiedler. (Eds.), The handbook of environmental chemistry Vol. 3, Part O Persistent organic pollutants (pp. 47-84). NB, E5B 1A1, Canada.

\section{Copyrights}

Copyright for this article is retained by the author(s), with first publication rights granted to the journal.

This is an open-access article distributed under the terms and conditions of the Creative Commons Attribution license (http://creativecommons.org/licenses/by/3.0/). 